\title{
ELEVEN YEARS OF MONITORING FLUORIDE CONTENT IN PUBLIC WATER SUPPLIES: METHODS, PRODUCTS, AND IMPORTANCE TO PUBLIC HEALTH
}

\author{
ONZE ANOS DE VIGILÂNCIA DOS TEORES DE FLÚOR NAS ÁGUAS DE \\ ABASTECIMENTO PÚBLICO: MÉTODOS, PRODUTOS E IMPORTÂNCIA PARA A \\ SAÚDE PÚBLICA
}

\author{
Suzely Adas Saliba MOIMAZ ${ }^{1}$; Luis Felipe Pupim dos SANTOS $^{2}$; Nemre Adas SALIBA ${ }^{3}$; \\ Orlando SALIBA ${ }^{4}$
}

1. Paulista State University (School of Dentistry of Araçatuba), Araçatuba, SP, Brazil; 2. Paulista State University (School of Dentistry of Araçatuba), Araçatuba, SP, Brazil. lfpupim@ @otmail.com; 3. Paulista State University (School of Dentistry of Araçatuba), Araçatuba, SP, Brazil; 4. Paulista State University (School of Dentistry of Araçatuba), Araçatuba, SP, Brazil.

\begin{abstract}
This study aimed to assay the development process and the characteristics of a program in uninterrupted activity for over 11 years, which monitors fluoride content in public water supplies, emphasizing the methodology used in the research, the services provided to cities and specificities of water distribution networks, the products derived from project implementation, the main results obtained in its course, and its importance in favor of public health. Monitoring is necessary to reach the maximum benefit in the prevention of tooth decay and minimum risk in fluorosis development. To develop the study, documents and reports of the project's database and the results of water samples were analyzed. A survey of the intellectual productions generated by the project was performed, maps of water distribution networks of 40 cities in the northwest region of São Paulo state included in the project were analyzed, and the research methodology was presented. The activities carried out in the project have been described with details regarding the main methodological aspects, such as the form of establishment of sample collection points, the laboratory methodology used for the analysis of water samples, the extension experience the project offers to all parties involved, the results of 11 years of sample analyses, the benefits generated to health managers and those responsible for water treatment, among other considerations on the cities. The methodology adopted by the project allows identifying areas where the population may be exposed to higher fluoride concentrations. From November 2004 to December 2015, 50.98\% of water samples from all cities were within the optimal parameters.
\end{abstract}

KEYWORDS: Fluoridation. Public Health Surveillance. Research Design.

\section{INTRODUCTION}

Public water fluoridation is one of the main and most important public health strategies, and it may be regarded as the most effective measure for controlling tooth decay, considering its wide scope (RAMIRES; BUZALAF, 2007). The method was so effective that the United States Center for Disease Control and Prevention (CDCP) considered it one of the top ten public health achievements of the twentieth century (CENTERS FOR DISEASE CONTROL AND PREVENTION, 2000).

The preventive effects of fluoride were discovered as a result of investigations on its toxic effect on dental enamel development, resulting from intake (PRADO et al., 2014). In 1942, a directly proportional correlation between the prevalence of dental fluorosis and fluoride ion concentration in drinking water was observed. On the other hand, a significant inversely proportional correlation was verified between the presence of fluoride ion and the prevalence of tooth decay. After determining these relations, new studies were designed to establish the best fluoride concentration in the water to generate the maximum benefit for preventing tooth decay and the lowest risk for developing dental fluorosis in the populations exposed (EIDELWEIN, 2010). Adding fluoride in public water supplies, as a public health measure to prevent tooth decay, began in 1945 with three pilot studies in cities of the United States (Grand Rapids, Michigan, and Newburgh, in the state of New York) and Canada (Brantford, Ontario). Control-cities were set for each of the aforementioned cities to compare the results, as follows: Muskegon and Kingston (United States), and Sarnia (Canada). These pioneering studies were seeking evidence that fluoridation might be a safe and feasible strategy to prevent tooth decay. It was concluded that the fluoride present in drinking water in a concentration of about 1 milligram per liter $(\mathrm{mg} / \mathrm{L})$ would promote the maximum reduction in the DMFT index, but values above $1.5 \mathrm{mg} / \mathrm{L}$ would not significantly improve the index and would increase the risk of developing dental fluorosis (NARVAI, 2000; KOZLOWSKI; PEREIRA, 2003). 
The water intake by the population may vary depending on the temperature of each location, because consumption tends to be higher in places with elevated temperatures. Thus, it was established that for each region the ideal levels of fluoride in drinking water should be recommended considering this variable (GALAGAN; VERMILLION, 1957).

In Brazil, the first city to adopt fluoridation in their water supply was Baixo Guandu, Espírito Santo, in 1953, and the Special Services Foundation in Public Health of the Ministry of Health was the public agency responsible for its operation (MOIMAZ; SANTOS, 2015). A study performed in this location proved that in the age group of 12 years, the DMFT index is $82 \%$ lower than before fluoridation (SALIBA et al., 2007). However, only in the 1970s the method became more effective through the approval of Federal Law n. 6050 of 1974, which stated the mandatory fluoridation in public water supply systems in locations with treatment plants (BRASIL, 1974). Ordinance n. 2,914 of 2011 issued by the Ministry of Health establishes the parameters considered acceptable for the potability of public water supplies for human consumption (BRASIL, 2011). According to this ordinance, the maximum fluoride content allowed is 1.5 milligrams per liter of water $(\mathrm{mgF} / \mathrm{L})$.

When the preventive properties of fluoride were discovered, it was believed that the beneficial effects occurred through the ion ability to form fluorapatite instead of hydroxyapatite in the stage of dental enamel production, allowing teeth to become more resistant to the acid surroundings caused by bacterial metabolism and their substrates (CHAVES, 1977). This current view considered that, once exposed to fluoride in the development stages of teeth, its preventive properties would be permanent for the individual (VIEGAS, 1989). However, it was proved that such a mechanism does not occur. Fluoride will provide higher teeth resistance through the enamel surface by periodic processes of surface demineralization and remineralization caused by the $\mathrm{pH}$ drop from the production of acids from dietary carbohydrates. The fluoride-containing tooth surface has lower solubility in acid surroundings compared to the original enamel surface (FEATHERSTONE, 1999). It is known that the beneficial effects attributed by fluoride are due to their continued presence in small amounts throughout the life of individuals (CURY, 1992).

Several researches indicate the need for monitoring fluoride content in the water to obtain the recommended standards (MAIA et al., 2003) (MOIMAZ; SANTOS, 2015). Therefore, external control, which is the control and periodic analysis of water fluoridation conducted by an institution apart from the one responsible for water treatment and supply, becomes an important strategy for the method to achieve its maximum benefit in preventing tooth decay and minimizing risks in the development of dental fluorosis.

Universities, due to their potential research implementation, their infrastructure, and for having professionals who do not only act in their own academic field but also benefit the population through research and extension projects, may play an important role for the community. Since 1991, the School of Dentistry of Araçatuba (FOA - Unesp) conducts a project that renders services to several cities in the northwest region of São Paulo state (Brazil), through the external control of fluoride in their public water supplies.

This study aimed to assay the development process and the characteristics of a program in uninterrupted activity for over 11 years, which monitors fluoride content in public water supplies, emphasizing the methodology used in the research, the services provided to cities and specificities of water distribution networks, the products derived from project implementation, the main results obtained in its course, and its importance in favor of public health.

\section{MATERIAL AND METHODS}

Descriptive study that verified activities performed, results, and products created from a research and extension project promoting the external control of fluoride. The study period covers the years between 1991 and 2015 .

The fluoride ion-monitoring project developed by the School of Dentistry of Araçatuba (FOA - Unesp) began in 1991 through an agreement between the university and the APCD (Paulista Association of Dental Surgeons); at that time, the analyses were conducted discontinuously. In its early years, the project aimed to comply with the request of the APCD to measure whether the water supply of some cities in the region of Araçatuba (São Paulo, Brasil) were presenting clinical conditions of dental fluorosis among their population.

To develop the study, documents and reports of the project's database and the results of water samples were analyzed. A survey of the intellectual productions generated by the project was performed, maps of water distribution networks of 40 cities in the northwest region of São Paulo state 
included in the project were analyzed, and the research methodology was presented.

The activities carried out in the project have been described with details regarding the main methodological aspects, such as the form of establishment of sample collection points, the laboratory methodology used for the analysis of water samples, the extension experience the project offers to all parties involved, the results of 11 years of sample analyses, the benefits generated to health managers and those responsible for water treatment, among other considerations on the cities.

The sample collection points were determined according to the amount and location of each water supply source. For each source, three collection points were chosen in the region supplied by it. The addresses of each point were selected, most of them in public places (schools, health centers, squares, among others), due to the easy access to collect water. Some studies determined the amount of collection points by population size; also some external control studies found in the literature showed specific results because their analyses were based on cross-sectional studies. The methodology adopted by the project of the FOA (Unesp) allows identifying areas where the population is most likely exposed to dental fluorosis, in addition to performing monthly and systematic monitoring of fluoride content, which is essential to obtain the maximum benefit and minimum risk of the method. Thus, considering the events showing results of inadequate fluoride content in samples, if the location has more than one source of water catchment, it is possible to know the specific areas where the population is prone to higher risks, assisting monitoring and water treatment services to identify and solve potential problems.

\section{RESULTS AND DISCUSSION}

Starting in 2004, a new project was announced aiming to continuously and systematically assess water samples from the public supply of 40 cities from the DRS-II (Regional Health Department) of the state of São Paulo, Brazil (Figure 1). These cities are: Alto Alegre , Andradina, Araçatuba, Auriflama, Avanhandava, Barbosa, Bento de Abreu, Birigui, Bilac, Braúna, Brejo Alegre, Buritama, Castilho, Clementina, Coroado, Gabriel Monteiro, Glicério, Guaraçaí, Guararapes, Guzolândia, Ilha Solteira, Itapura, Lavínia, Lourdes, Luiziânia, Mirandópolis, Murutinga do Sul, Nova Castilho, Nova Independência, Nova Luzitânia, Penápolis, Pereira Barreto, Piacatú, Rubiácea, Santo Antônio do Aracanguá, Santópolis do Aguapeí, Sud Mennucci, Suzanápolis, Turiúba, and Valparaíso.

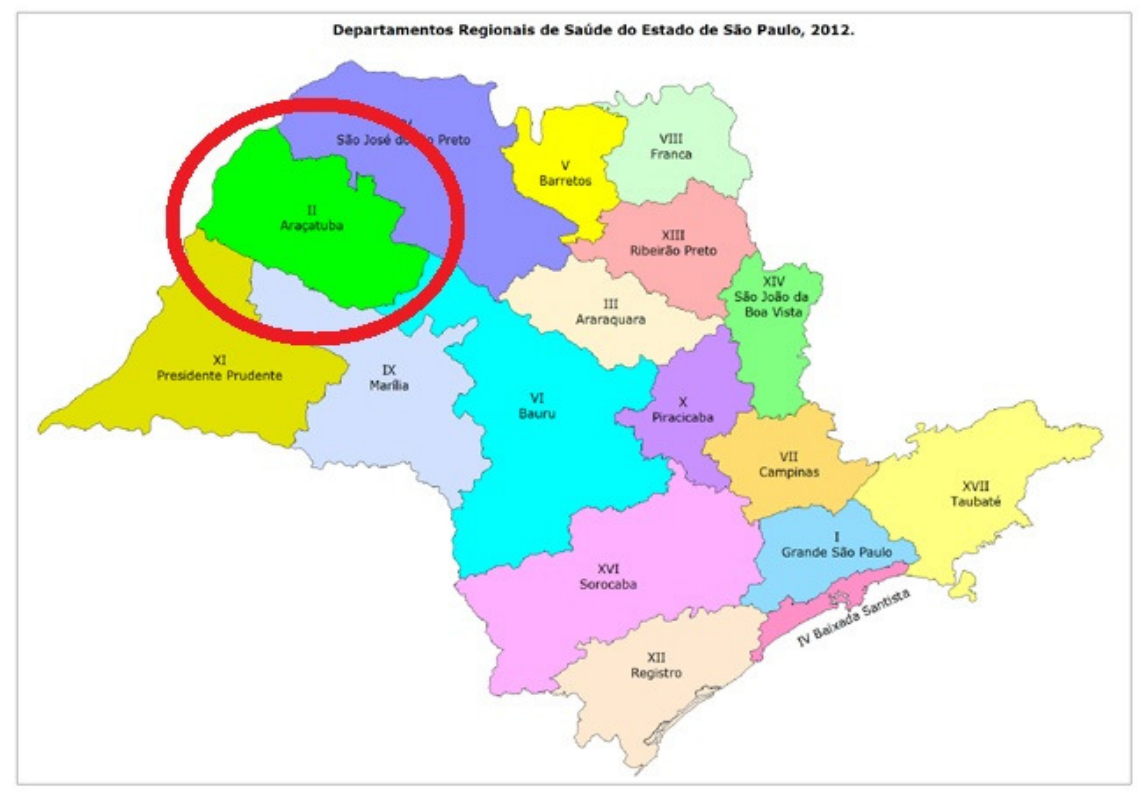

Figure 1. Map of the State of São Paulo with the region from the DRS-II circled in red, showing the area with the cities included in the project of fluoride external control. 
For determining the location of sample collection points, the water distribution networks of the 40 cities were analyzed. Oral health coordinators and technicians responsible for the water treatment of all cities were interviewed at the time. Thus, information on sources of natural water and distribution networks were obtained and analyzed.

The project activities are implemented as follows: in the NEPESCO (Research Center in Public Health) laboratory, 40-ml polyethylene airtight bottles are properly cleaned and decontaminated with deionized water, receiving an identification tag with data relating to collection site, day, month, time, and name of the responsible person; these bottles are sent to the cities. After the water is collected, the samples are sent back to the FOA (Unesp) where the analyses are carried out within 150 days.

The method used to analyze fluoride content is based on that described by Maia et al. (2003) with an ORION EA 940 potentiometer coupled to a combined electrode (Orion 9609BN) designed for reading the fluoride ion.

The equipment is calibrated in triplicate by constructing a calibration curve in order to reduce the margin of error, taking into account the expected values for the samples with standards ranging from 0.1 to $2.0 \mathrm{mgF} / \mathrm{L}$. Thus, dilutions from a standard
$100 \mathrm{mg} / \mathrm{L}$ fluoride solution (Orion 940907) were used. From each one of the five standards, a volume of $1 \mathrm{ml}$ was collected, which was later added by 1 $\mathrm{ml}$ of Total Ionic Strength Adjuster Buffer (TISAB II), a $\mathrm{pH}$, ionic strength adjusting buffer commonly used in fluoride analyses. The values obtained in the readings of the duplicate samples, also added by TISAB II (1:1), were transferred to a Microsoft Excel spreadsheet and converted from millivolts $(\mathrm{mV})$ to milligrams of fluoride per liter $(\mathrm{mgF} / \mathrm{L})$, and analyzed using descriptive statistics.

Those responsible for water treatment Secretary of Health and municipal Oral Health Coordinator, are informed monthly about the results of sample analyses, becoming aware of the situation of their cities concerning fluoride content.

For the analysis of results on fluoride content, the project uses the classification prepared by the Collaborating Center of the Ministry of Health in Oral Health Surveillance (CECOL) of the Public Health School of the University of São Paulo, which is based on the principle of higher benefit for preventing caries and lower risk of developing dental fluorosis, also considering the average maximum temperature of each location (Chart 1) (UNIVERSIDADE DE SÃO PAULO, 2011).

Chart 1. Fluoride concentrations and the benefit and risk levels of locations whose average maximum temperatures are between $32.5^{\circ} \mathrm{C}$ and $26.3^{\circ} \mathrm{C}$, according to the CECOL.

\begin{tabular}{|l|l|l|}
\hline $\begin{array}{c}\text { Fluoride content in water }(\mathrm{mg} \\
\mathrm{F} / \mathrm{L})\end{array}$ & \multicolumn{1}{|c|}{ Benefit (caries prevention) } & \multicolumn{1}{c|}{$\begin{array}{c}\text { Risk (dental fluorosis } \\
\text { production) }\end{array}$} \\
\hline $0.00-0.44$ & Insignificant & Insignificant \\
\hline $0.45-0.54$ & Minimum & Low \\
\hline $\mathbf{0 5 5}-\mathbf{0 . 8 4}(*)$ & Maximum & Low \\
\hline $0.85-1.14$ & Maximum & Moderate \\
\hline $1.15-1.44$ & Questionable & High \\
\hline 1.45 or more & Ill effects & Very high \\
\hline
\end{tabular}

Table 1. Cities, amount of water collection points, origin of fluoride in water, means and standard deviations for the years 2005 and 2015 .

\begin{tabular}{lcccccc}
\hline & Amount of & & \multicolumn{2}{c}{2005} & \multicolumn{2}{c}{2015} \\
\cline { 4 - 7 } \multicolumn{1}{c}{ City } & $\begin{array}{c}\text { water } \\
\text { collection } \\
\text { points }\end{array}$ & Fluoride origin & Mean & SD & Mean & SD \\
\hline Alto Alegre & 3 & Added & 0.67 & 0.08 & 0.78 & 0.08 \\
Andradina & 3 & Natural & 0.77 & 0.22 & 0.76 & 0.17 \\
Araçatuba & 9 & Added & 0.53 & 0.14 & 0.65 & 0.08 \\
Auriflama & 3 & Natural & 0.42 & 0.32 & 0.69 & 0.13 \\
Avanhandava & 3 & Added & 0.66 & 0.21 & 0.77 & 0.08 \\
Barbosa & 9 & Added & 0.64 & 0.29 & 0.73 & 0.18 \\
Bento de Abreu & 3 & Added & 0.60 & 0.10 & 0.80 & 0.54 \\
Bilac & 12 & Added & 0.60 & 0.33 & 0.71 & 0.37
\end{tabular}




\begin{tabular}{|c|c|c|c|c|c|c|}
\hline & & Natural and & & & & \\
\hline Birigui & 42 & Added & 0.62 & 0.29 & 0.80 & 0.22 \\
\hline Braúna & 9 & Added & 0.05 & 0.02 & 0.79 & 0.17 \\
\hline Brejo Alegre & 3 & Added & 0.59 & 0.09 & 0.67 & 0.05 \\
\hline Buritama & 24 & Added & 0.08 & 0.04 & 0.81 & 0.42 \\
\hline Castilho & 15 & Added & 0.62 & 0.20 & 0.80 & 0.30 \\
\hline Clementina & 18 & Added & 0.07 & 0.03 & 0.72 & 0.16 \\
\hline Coroados & 3 & Added & 0.71 & 0.06 & 0.70 & 0.12 \\
\hline Gabriel Monteiro & 3 & Added & 0.67 & 0.07 & 0.87 & 0.25 \\
\hline Glicério & 9 & Natural & 0.33 & 0.18 & 0.66 & 0.12 \\
\hline Guaraçai & 12 & Added & 0.47 & 0.19 & 0.70 & 0.14 \\
\hline Guararapes & 3 & Added & 0.61 & 0.06 & 0.74 & 0.03 \\
\hline Guzolândia & 3 & Added & 0.67 & 0.05 & 0.73 & 0.07 \\
\hline Ilha Solteira & 3 & Added & 0.66 & 0.07 & 0.77 & 0.15 \\
\hline Itapura & 12 & Added & 0.39 & 0.24 & 0.75 & 0.41 \\
\hline Lavínia & 12 & Added & 0.30 & 0.25 & 0.53 & 0.35 \\
\hline Lourdes & 3 & Added & 0.56 & 0.08 & 0.71 & 0.08 \\
\hline Luiziânia & 3 & Natural & 0.63 & 0.14 & 0.75 & 0.23 \\
\hline Mirandópolis & 6 & Added & 0.69 & 0.17 & 0.70 & 0.12 \\
\hline Murutinga do Sul & 3 & Added & 0.37 & 0.12 & 0.24 & 0.06 \\
\hline Nova Castilho & 3 & Added & 0.52 & 0.09 & 0.93 & 0.34 \\
\hline Nova Independência & 6 & Added & 0.69 & 0.40 & 0.71 & 0.11 \\
\hline Nova Luzitânia & 3 & Added & 0.57 & 0.11 & 0.53 & 0.26 \\
\hline Penápolis & 3 & Added & 0.66 & 0.06 & 0.77 & 0.10 \\
\hline Pereira Barreto & 3 & Natural & 0.79 & 0.07 & 0.75 & 0.14 \\
\hline Piacatú & 3 & Added & 0.61 & 0.09 & 0.71 & 0.10 \\
\hline Rubiácea & 6 & Added & 0.64 & 0.21 & 0.74 & 0.10 \\
\hline Santo Antônio do & & Added & & & & \\
\hline Aracanguá & 6 & & 0.40 & 0.36 & 0.69 & 0.15 \\
\hline Santópolis do & & Added & & & & \\
\hline Aguapeí & 3 & & 0.66 & 0.12 & 0.97 & 0.13 \\
\hline Sud Mennucci & 3 & Added & 0.57 & 0.07 & 0.67 & 0.04 \\
\hline Suzanápolis & 9 & Added & 0.91 & 0.13 & 0.33 & 0.12 \\
\hline Turiúba & 3 & Added & 0.59 & 0.07 & 0.71 & 0.08 \\
\hline Valparaíso & 9 & Added & 0.72 & 0.20 & 0.99 & 0.33 \\
\hline Total & 291 & & & & & \\
\hline
\end{tabular}

Table 2. Percentage distribution of water samples according to the fluoride content of the 40 cities included in the project of external control, with data from November 2004 to December 2015.

\begin{tabular}{lcc}
\hline $\mathbf{m g F} / \mathbf{L}$ & $\mathbf{n}$ & $\mathbf{\%}$ \\
\hline$<0.55$ & 7547 & 25.67 \\
from 0.55 to 0.84 & 14988 & 50.98 \\
from 0.85 to 1.14 & 5505 & 18.73 \\
$>1.14$ & 1358 & 4.62 \\
Total & $\mathbf{2 9 3 9 8}$ & $\mathbf{1 0 0}$ \\
\hline
\end{tabular}


In Table 1, comparing the means of the first year of implementation of monthly analyses of the project (2005) to the year 2015 showed that some cities have adapted the fluoride content in their drinking water to the recommended values, as follows: Auriflama, Braúna, Buritama, Clementina, Glicério, Guaraçaí, Itapura, and Santo Antônio do Aracanguá. Not every city, however, has adopted the method. It is also observed that most of the cities, in 2015, presents optimal amounts of fluoride. In Table 2, the percentage distribution of water sample results of all cities, from November 2004 to December 2015, by monthly analyses, clearly shows that half of them are within the range that provides the greatest benefit and minimal risk.

Some cities, such as Birigui, show a complex distribution network with several water catchment sources composing its supply system, including deep wells. The deep wells are namely Aqua Pérola and Matéria, both from the Guarani aquifer. Studies conducted in the cities show that the fluoride content of these wells are above the recommended values, with approximately $51 \%$ of their samples with values above 0.84 milligrams of fluoride per liter (mgF/L) (MOIMAZ; SANTOS,
2015). An epidemiological study conducted in the city of Birigui also found high presence of fluorosis in 12 year-old children enrolled in public educational institutions, showing a significant association between the presence of the disease and the areas with excess fluoride in the water supply (MARQUES, 2008); hence the importance of establishing collection points according to the supply sources. In 2011, an agreement between the city of Birigui and the School of Dentistry of Araçatuba (FOA process-1457/2010, additive-term 01) was signed, so to officially continue the project activities.

Studies aiming to investigate the prevalence of dental fluorosis in Brazil have begun in 1970 with a survey conducted in the city of Pereira Barreto (one of the cities included in the project of external control), where fluoride concentration in the water was $20 \mathrm{mgF} / \mathrm{L}$, an extremely high value. From 442 children examined, only $21 \%$ were fluorosis-free (SALIBA; UCHÔA, 1970). During the year of 2015, with monthly collections of water, the mean fluoride concentration of this city was 0.75 $\mathrm{mgF} / \mathrm{L}$ and standard deviation was 0.14 . The source of water supply for this location is a deep well.

Chart 2. Papers published in scientific journals by the project, since 1991.

\begin{tabular}{|l|c|}
\hline $\begin{array}{l}\text { Reduction in the prevalence of dental caries after ten years of public water supply } \\
\text { fluoridation in the city of Birigui, SP, Brazil. }\end{array}$ & 1995 \\
\hline $\begin{array}{l}\text { Reduction of dental caries in schoolchildren from Araçatuba, SP, Brazil, after 21 years } \\
\text { of public water supply fluoridation. }\end{array}$ & 1996 \\
\hline Recommendations to using fluoridated dietary supplements. & 1999 \\
\hline Dental fluorosis in children from public schools in the city of Araçatuba, SP, Brazil. & 1999 \\
\hline $\begin{array}{l}\text { Fluorosis self-perception in schoolchildren aged 11 to 12 years: Pereira Barreto, SP, } \\
\text { Brazil - 1999. }\end{array}$ & 1999 \\
\hline Scientific basis for the correct diagnosis of dental fluorosis. & 2002 \\
\hline Prevalence of dental fluorosis in schoolchildren from Marinópolis, São Paulo, Brazil. & 2002 \\
\hline $\begin{array}{l}\text { Prevalence of dental fluorosis in deciduous dentition in children participating of health } \\
\text { prevention and promotion programs in the city of Marília, SP, Brazil. }\end{array}$ & 2002 \\
\hline $\begin{array}{l}\text { Assessment of the effect of two fluoridated chewing gums on cariogenic microbiota of } \\
\text { saliva and on plaque. }\end{array}$ & 2003 \\
\hline $\begin{array}{l}\text { Verification of residual fluoride content in the saliva of children subjected to preventive } \\
\text { methods. }\end{array}$ & 2003 \\
\hline Need for advertisement regulations and re-adequacy of labels of mineral water packings. & 2003 \\
\hline Legislation on fluoride applications in water and dental products. & 2003 \\
\hline $\begin{array}{l}\text { External control of fluoride content in the public water supply of the city of Lins, SP, } \\
\text { Brazil. }\end{array}$ & 2004 \\
\hline Milk as fluoride source. & 2004 \\
\hline Fluoridation in the northwest region of the state of São Paulo, Brazil. & 2004 \\
\hline $\begin{array}{l}\text { Participation of coordinators of public dental services in the process of monitoring water } \\
\text { fluoridation. }\end{array}$ & 2005 \\
\hline $\begin{array}{l}\text { Fluoride content in public water supplies of cities in the northwest region of the state of } \\
\text { São Paulo, Brazil. }\end{array}$ & 2006 \\
\hline
\end{tabular}




\begin{tabular}{|c|c|}
\hline Importance of sanitary surveillance and health education for preventing dental fluorosis. & 2006 \\
\hline $\begin{array}{l}\text { Dental fluorosis in young persons not exposed to fluoridated water during dental } \\
\text { formation. }\end{array}$ & 2006 \\
\hline Analysis of fluoride concentration in maternal milk substitutes. & 2006 \\
\hline $\begin{array}{l}\text { Decrease of caries in a city of the northwest region of the state of São Paulo, Brazil, } \\
\text { from } 1998 \text { to } 2004 .\end{array}$ & 2006 \\
\hline $\begin{array}{l}\text { Consumer alert! Does the fluoride concentration described in mineral water labels } \\
\text { protect from caries? }\end{array}$ & 2006 \\
\hline $\begin{array}{l}\text { Dental fluorosis in cities with different periods of fluoride addition to public water } \\
\text { supplies. }\end{array}$ & 2006 \\
\hline Children free from dental caries in a city with no fluoridated water. & 2007 \\
\hline Dental caries in permanent residents of Baixo Guandu, Brazil, fluoridated since 1953. & 2007 \\
\hline $\begin{array}{l}\text { Analysis of the fluoridation process in the northwest region of São Paulo, Brazil, in the } \\
\text { view of the oral health coordinator. }\end{array}$ & 2007 \\
\hline The importance of external control of public water supply fluoridation. & 2007 \\
\hline $\begin{array}{l}\text { Dental fluorosis in the population of Baixo Guandu, ES, Brazil, after } 50 \text { years of water } \\
\text { fluoridation: comparison with the city of Itarana, ES, Brazil. }\end{array}$ & 2007 \\
\hline $\begin{array}{l}\text { Dental caries of permanent residents of Baixo Guandu, Brazil, fluoridated since } 1953 \text { - a } \\
\text { brief communication. }\end{array}$ & 2008 \\
\hline $\begin{array}{l}\text { Association between breastfeeding practices and sucking habits: a cross-sectional study } \\
\text { of children in their first year of life. }\end{array}$ & 2008 \\
\hline $\begin{array}{l}\text { Urinary fluoride excretion in children exposed to fluoride toothpaste and to different } \\
\text { water fluoride contents in a tropical area of Brazil. }\end{array}$ & 2008 \\
\hline Effects of fluoride intake on insulin sensitivity and insulin signal transduction. & 2008 \\
\hline Prevalence of enamel white spots and risk factors in children up to 36 months old. & 2009 \\
\hline $\begin{array}{l}\text { Fluoride intake from meals served in daycare centers in cities with different fluoride } \\
\text { concentrations in the water supply. }\end{array}$ & 2009 \\
\hline $\begin{array}{l}\text { Dental caries prevalence in children up to } 36 \text { months of age attending daycare centers in } \\
\text { cities with different water fluoride content. }\end{array}$ & 2009 \\
\hline $\begin{array}{l}\text { Fluoride content monitoring of the public water supply of the northwest region of the } \\
\text { state of São Paulo, Brazil: 36-month analysis. }\end{array}$ & 2009 \\
\hline Infant formula and enamel fluorosis. & 2009 \\
\hline $\begin{array}{l}\text { A comparative analysis of caries and fluorosis among cities with and without public } \\
\text { water supply fluoridation in the state of São Paulo, Brazil. }\end{array}$ & 2009 \\
\hline $\begin{array}{l}\text { Insulin signal decrease in the muscle but not in the liver of castrated male rats from } \\
\text { chronic exposure to fluoride. }\end{array}$ & 2010 \\
\hline Public water supply fluoridation in cities with different sources of water catchment. & 2011 \\
\hline $\begin{array}{l}\mathrm{NaF} \text { treatment increases TNF- } \alpha \text { and resistin concentrations, and reduces insulin signal in } \\
\text { rats. }\end{array}$ & 2012 \\
\hline External control of public water supplies in 29 Brazilian cities. & 2012 \\
\hline Public water supply fluoridation in the city of Araçatuba, SP, Brazil. & 2012 \\
\hline Fluoride content in the water of surface wells. & 2012 \\
\hline $\begin{array}{l}\text { Monitoring of fluoride content in the public water supply of Araçatuba, SP, Brazil - 12- } \\
\text { month analysis. }\end{array}$ & 2012 \\
\hline Influence of rainfall variation on fluoride contents of water from wells. & 2012 \\
\hline Fluoride concentration in public water supply: 72-months analysis. & 2012 \\
\hline Water fluoridation in 40 Brazilian cities: 7-year analysis. & 2013 \\
\hline Dental fluorosis and its influence on the lives of children. & 2015 \\
\hline $\begin{array}{l}\text { Longitudinal study on water fluoridation in cities with complex distribution network: } \\
\text { ten-year study. }\end{array}$ & 2015 \\
\hline Study on fluoride concentration in public water supplies relc & 2016 \\
\hline
\end{tabular}

The project was responsible for more than fifty papers published in scientific journals (Chart
2), including not only laboratory researches but also large epidemiological studies performed in several 
locations, especially those where fluoride in drinking water was assumed to cause risks to the population. The contributions that these studies provide are not restricted to the scientific community. The findings and conclusions of each of them contribute to the maximum understanding of the characteristics, qualities, and potential limitations of the method, so that new knowledge is disseminated nationally and internationally, expanding the technical and scientific knowledge on the subject for researchers, teachers, and professionals responsible for water treatment.

In 2011, Ordinance n. 518/2004 was revoked, and therefore, Ordinance n. 2914 has become the current regulation for the potability of water intended for human consumption. The review of Ordinance MS n. 518/2004 considered advances in technical and scientific knowledge, international experiences, and the recommendations of the 4th Edition of the Guidelines for Drinking-Water Quality from the World Health Organization, adapted to the Brazilian reality (BRASIL, 2012). According to the ordinance, the maximum fluoride ion allowed is $1.5 \mathrm{mgF} / \mathrm{L}$. Ordinance n. 635/GM/MS of 01/30/1976, which approves norms and standards on water fluoridation of public water supply systems for human consumption, sets recommended limits to fluoride concentration based on the maximum daily average temperatures. Thus, states may create laws by setting minimum and maximum amounts of fluoride contained in their municipal water supplies according to the average maximum temperature of each location, however, not exceeding the maximum allowed of $1.5 \mathrm{mgF} / \mathrm{L}$. For the state of São Paulo, for example, the SS Resolution - 250/95 sets an optimal concentration of fluoride in water intended for human consumption in the range of 0.6 to 0.8 mgF/L (SÃO PAULO, 1995).

The project contributes to the professional qualification of undergraduate students, postgraduate students, teachers, and technicians, training them for research and field activities, generating benefits for all parties involved - the cities, the university, and the community. The cities are benefited with information about the fluoride content present in their drinking water provided monthly to health coordinators, oral health secretaries, and technicians responsible for water treatment. One of the challenges of the water fluoridation method is that external control is difficult in small- and medium-sized cities, due to the lack of laboratory infrastructure and technical expertise to carry out periodic analyses (SALIBA et al., 2009). The university is favored by the research conducted, thus spreading their work to the academic world, helping to improve the method with new findings, reducing risks, and maximizing benefits. The university also provides the involved students with the experience of participating in a project that works directly in association with the Regional Board of Health and the cities, providing the most extensive operational knowledge on guidelines and public health service, technical standards, reports, and federal laws that govern and regulate fluoridation, and on the operation of water distribution networks. Hence, the community eventually becomes the main beneficiary of the project activities, with access to water within the ideal standards of fluoride content.

Over the years of the project, several meetings were held with the heads of each city to update the information on their respective water supply systems. In these meetings, the main difficulties in obtaining control of the optimal fluoride content are checked, analyzed, and discussed with the municipal authorities, besides promoting discussions about the importance of external control in public water supplies to prevent tooth decay and to the risks of dental fluorosis development. In cities with greater variability of results, meetings were carried out "in situ" with the technicians responsible for water treatment, aiming to identify and try to solve the difficulties detected regarding the settlement of adequate fluoride content in water. This service provides managers and health professionals with conditions to plan their actions in public health and ensure that the entire population may receive quality water.

The integration of universities with health and surveillance services and other social institutions is important and should be encouraged, because they generate benefits to all involved. Fluoridation of public water supplies is an already established method and several studies prove its benefits. However, monitoring is necessary so that contents are within the ideal parameters. Clinical cases of dental fluorosis, although rare today, may occur in certain locations. In order to study and reverse this phenomenon, it is important to have information regarding the mapping of distribution networks in each city, as well as constantly monitoring its waters. Locations with no fluoridated water supplies should be encouraged to adopt the method, so it continues providing benefits for tooth decay prevention.

\section{CONCLUSION}

For over 11 years, the project of external control of fluoride, carried out by the School of 
Dentistry of Araçatuba monthly analyzes water samples from 40 cities in northwestern São Paulo (Brazil). The methodology adopted by the project allows identifying areas where the population may be exposed to higher concentrations of fluoride. From November 2004 to December 2015, 50.98\% of water samples from all cities were within the optimal parameters. Monitoring is necessary to reach the maximum benefit in the prevention of tooth decay and minimum risk in fluorosis development.

RESUMO: O objetivo deste estudo foi analisar o processo de desenvolvimento e as características de um programa em atividade ininterrupta há mais de 11 anos, que realiza o monitoramento do nível de flúor nas águas de abastecimento público, enfatizando a metodologia utilizada na pesquisa; os serviços prestados para as cidades e as especificidades das redes de distribuição de água; produtos gerados com a implementação do projeto; os principais resultados obtidos em seu curso; e sua importância em favor da saúde pública. A vigilância do método é necessária para se alcançar o máximo benefício na prevenção da cárie dentária e mínimo risco no desenvolvimento de fluorose. Para o desenvolvimento do estudo, foram feitas análises documentais e de relatórios do banco de dados do projeto e os resultados das amostras de água. Foi realizado um levantamento das produções intelectuais que o projeto gerou, a análise dos mapas de redes de distribuição de água das 40 cidades do noroeste do estado de São Paulo incluídas no projeto, e apresentação da metodologia de pesquisa. As atividades desenvolvidas no projeto foram descritas com detalhes quanto aos principais aspectos metodológicos, tais como: a forma de estabelecimento de pontos de coleta das amostras; a metodologia laboratorial utilizada para a análise de amostras de água; a experiência extensionista que o projeto oferece a todas as partes envolvidas; os resultados de 11 anos de análise das amostras; os benefícios gerados para os gestores de saúde e os responsáveis pelo tratamento de água; entre outras considerações sobre as cidades. A metodologia adotada pelo projeto permite a identificação de áreas onde a população pode estar exposta a altas concentrações de flúor. De novembro de 2004 a dezembro de $2015,50,98 \%$ das amostras de água de todas as cidades estavam dentro dos parâmetros ideais.

PALAVRAS-CHAVE: Fluoretação. Vigilância em Saúde Pública. Projetos de pesquisa.

\section{REFERENCES}

BRASIL. Lei no 6.050, de 24 de maio de 1974. Dispõe sobre a obrigatoriedade da fluoretação das águas em sistema de abastecimento. Disponível em:

<http://dtr2004.saude.gov.br/dab/docs/legislacao/decreto76842_22_12_75.pdf>. Acesso em 16 jan. 2016.

BRASIL. Perguntas frequentes sobre a Portaria MS n 2.914/2011. 2012. Disponível em:

<http://www.baktron.com.br/img/ManagerImages/perguntas\%20e\%20respostas\%20sobre\%20a\%20portaria\%2 0ms\%20n\%202\%20914\%20de\%202011.pdf>. Acesso em 16 jan. 2016.

BRASIL. Portaria n⿳ 2914, de 12 de dezembro de 2011. Dispõe sobre os procedimentos de controle e de vigilância da qualidade da água para consumo humano e seu padrão de potabilidade. Disponível em: <http://bvsms.saude.gov.br/bvs/saudelegis/gm/2011/ prt2914_12_12_2011.html>. Acesso em 16 jan. 2016.

CENTERS FOR DISEASE CONTROL AND PREVENTION. Achievements in public health, 1900- 1999, fluoridation of drinking water to prevent dental caries. JAMA, Chicago, v. 283, n. 10, p. 1283-1286, Mar. 2000. https://doi.org/10.1001/jama.283.10.1283

CHAVES, M. M. Odontologia social. 2. ed. Labor: Rio de Janeiro, 1977. 448 p.

CURY, J. A. Flúor: dos 8 aos 80? In: BOTTINO, M. A.; FELLER, C. (Org.). Atualização na clínica odontológica. São Paulo: Artes Médicas, 1992. p. 375-382.

EIDELWEIN, C. Panorama, benefícios e controvérsias da fluoretação da água de abastecimento público no Brasil e no mundo: uma revisão de literatura. 2010. 61 f. Monografia (Especialização) - Universidade Federal do Rio Grande do Sul, Porto Alegre, 2010.

FEATHERSTONE, J. D. Prevention and reversal of dental caries: role of low level fluoride. Community Dent. Oral Epidemiol., Copenhagen, v. 27, n. 1, p. 31-40, Feb. 1999. 
GAlAGAN, D. J.; VERMILliOn, J. R. Determining optimum fluoride concentrations. Public Health Rep., Washington, v. 72, n. 6, p. 491-493, Jun. 1957.

KOZLOWSKI, F. C.; PEREIRA, A. C. Métodos de utilização de flúor sistêmico. In: PEREIRA, A. C. (Org.). Odontologia em saúde coletiva. Porto Alegre: Artmed; 2003. p. 265-274.

MAIA, L. C.; VALENÇA, A. M. G.; SOARES, E. L.; CURY, J. A. Controle operacional da fluoretação da água de Niterói, Rio de Janeiro, Brasil. Cad. Saúde Pública, Rio de Janeiro, v. 196, n. 1, p. 61-67, Jan./Feb. 2003.

MARQUES, L. B. Prevalência e autopercepção da fluorose dentária em crianças de 12 anos de idade em Biriguii-SP. 2008. 66 f. Dissertação (Mestrado) - Faculdade de Odontologia, Universidade Estadual Paulista, Araçatuba, 2008

MOIMAZ, S. A. S.; SANTOS, L. F. P. Estudo longitudinal da fluoretação das águas em município com complexa rede de distribuição: dez anos de estudo. Arch. Health Invest., Araçatuba, v. 4, n. 5, p. 11-16, 2015.

NARVAI, P. C. Cárie dentária e flúor: uma relação do século XX. Ciênc. Saúde Coletiva, Rio de Janeiro, v. 5, n. 2, p. 381-392, jan. 2000.

PRADO, J. R. S.; NUNES, J. G.; HINNAH, S. S.; MARCHETTO, M. Fluoretação em água de abastecimento e a saúde pública. E\&S Eng. Sci., Cuiabá, v. 2, n. 1, p. 66-76, 2014.

RAMIRES, I.; BUZALAF, M. A. R. A fluoretação da água de abastecimento público e seus benefícios no controle da cárie dentária - cinquenta anos no Brasil. Ciênc. Saúde Coletiva, Rio de Janeiro, v. 12, n. 4, p. 1057-1065, 2007.

SALIBA, N. A.; MOIMAZ, S. A. S.; CASOTTI, C. A.; TIANO, A. V. P. Cárie dentária em residentes permanentes de Baixo Guandu, Brasil, fluoretada desde 1953. FES Rev. Odontol., Vitória, v. 9, n. 2, p. 16-21, maio/ago. 2007.

SALIBA, N. A.; MOIMAZ, S. A. S.; SALIBA, O.; BARBOSA, T. F. Fluoride content monitoring of the public water supply of the Northwest area of the state of São Paulo, Brazil: 36-month analysis. Rev. Odonto Ciênc., Porto Alegre, v. 24, n. 4, p. 372-376, Oct./Dec. 2009.

SALIBA, N. A.; UCHÔA, H. W. Prevalência da fluorose dental na cidade de Pereira Barreto. Bol. Serv. Odontol. Sanit. Sec. Saúde Rio Grande do Sul, Porto Alegre, v. 5, n. 3, 1970.

SÃO PAULO. Secretaria de Estado da Saúde. Resolução SS-250, de 15 de agosto de 1995. Define teores de concentração do íon fluoreto nas águas para consumo humano, fornecidas por sistemas públicos de abastecimento. Disponível em: <http://www.mpsp.mp.br/ portal/page/ portal/cao_consumidor/ legislacao/leg_servicos_publico/leg_sp_agua/resol-SS-250-95.pdf>. Acesso em 16 jan. 2016.

UNIVERSIDADE DE SÃO PAULO. Classificação de águas de abastecimento público segundo o teor de flúor. São Paulo: Faculdade de Saúde Pública, 2011. Disponível em: $<$ http://www.cecol.fsp.usp.br/dcms/uploads/arquivos/1398177715_CECOL-USP-

ClassificacaoAguasSegundoTeorFluor-DocumentoConsensoTecnico-2011.pdf>. Acesso em 16 jan. 2016.

VIEGAS, A. R. Fluoretação da água de abastecimento público. Rev. Bras. Med., São Paulo, v. 46, n. 6, p. 209216, 1989. 